\section{A Nursery and Greenhouse Online Knowledge Center: Learning Opportunities for Sustainable Practice}

\author{
John D. Lea-Cox ${ }^{1,13}$, Cindy Zhao ${ }^{1}$, David S. Ross ${ }^{2}$, \\ Theodore E. Bilderback ${ }^{3}$, J. Roger Harris ${ }^{4}$, Susan D. Day ${ }^{5}$, \\ Chuanxue Hong ${ }^{6}$, Thomas H. Yeager ${ }^{7}$, Richard C. Beeson, Jr. ${ }^{8}$, \\ William L. Bauerle ${ }^{9}$, Andrew G. Ristvey ${ }^{10}$, Mary Lorscheider ${ }^{11}$, \\ Sarah Dickinson ${ }^{4}$, and John M. Ruter ${ }^{12}$
}

\begin{abstract}
ADDITIONAL INDEX WORDS. irrigation, fertilization, surface water management, pathogens, Moodle, distance-learning modules
\end{abstract}

SUMMARY. Increasing environmental concerns and legislation in many states and in other countries require that we take a more comprehensive sustainable "best management" approach to production techniques in nursery and greenhouse operations. This is particularly important because these production facilities are typically intense users of resources that are applied to relatively small land areas. We have developed an online knowledge center to facilitate the implementation of more sustainable practices within the nursery and greenhouse industry. A web-based knowledge center provides the most cost-effective mechanism for information delivery, as our potential audiences are extremely diverse and widespread. We currently have a registered user database of over 450 educators, growers, and industry professionals, and undergraduate and graduate students. A gateway website provides an overview of the issues and the goals of the project. The associated knowledge center currently has 25 in-depth learning modules, designed in a Moodle learning management framework. These learning modules are designed to actively engage learners in topics on substrate, irrigation, surface water, and nutrient and crop health management, which are integral to formulating farmspecific strategies for more sustainable water and nutrient management practices. Additional modules provide assessment and implementation tools for irrigation audits, irrigation methods and technologies, and water and nutrient management planning. The instructional design of the learning modules was paramount because there can be multiple strategies to improve site-specific production practices, which often require an integration of knowledge from engineering, plant science, and plant pathology disciplines. The assessment and review of current practices, and the decision to change a practice, are often not linear, nor simple. All modules were designed with this process in mind, and include numerous resources [pictures, diagrams, case studies, and assessment tools (e.g., spreadsheets and example calculations)] to enable the learner to fully understand all of the options available and to think critically about his/her decisions. Sixteen of the modules were used to teach an intensive 400-level "Principles of Water and Nutrient Management" course at the University of Maryland during Spring 2008 and 2009. The water and nutrient management planning module also supports the nursery and greenhouse Farmer Training Certification program in Maryland. The Maryland Department of Agriculture provides continuing education credits for all consultants and growers who register and complete any module in the knowledge center. Although these learning resources were developed by faculty in the eastern region of the United States, much of the information is applicable to more widespread audiences.

$\mathrm{T}$ The majority of ornamental plants grown in the United States are produced in container-nursery or greenhouse operations. These operations are classified as intensive agricultural systems because they use a combination of expensive resources (labor, water, fertilizers, etc.) to produce plants in large numbers on small acreages. The nursery/ greenhouse industry ranks fifth (>\$14.6 billion) in U.S. agriculture and is in the top five commodities for 26 states [U.S. Department of Agriculture (USDA), 2004]. In 2002, the ornamental industry had 4.82 million acres in production, accounting for $15.4 \%$ of wholesale crop receipts, with an average net return of $\$ 947$ per acre (USDA, 2004). The industry is highly diverse in terms of production practices and the species of plants grown, with $\approx 400$ genera and more than 2000 species of ornamentals in production. Container-nursery and greenhouse systems differ radically from traditional agronomic-type agricultural operations in terms of how they use water and nutrients. This is because these farms produce plants in soilless substrates that differ markedly in how they retain water and nutrients in comparison with traditional soils.

Water issues, specifically irrigation scheduling, surface water management, and water quality, are quickly becoming topics of major concern to the industry even in what are thought of as water-rich states. Various factors, including drought, urban competition for fresh water resources, environmental concerns about runoff on water quality, and legislation at state and county levels, are increasing the need for ornamental producers to manage water more effectively (Fernandez et al., 2009). Water and nutrient management has been a major concern of growers and organizations for many years (Beeson et al., 2004). Prompted by a mutual concern over water supplies, four diverse green industry associations, namely, the American Nursery and Landscape Association (ANLA), the Professional Landcare Network (PLANET), the Irrigation Association (IA), and Turfgrass Producers International (TPI) joined together to form the Green Associations Water Conservation Council to effectively address local and regional water-use issues by these organizations. Legislation regarding water use and/or quality has currently been implemented in eight states around the United States (Fernandez et al., 2009). This regulation and increasing

\begin{tabular}{llll}
\hline $\begin{array}{l}\text { Units } \\
\text { To convert U.S. to SI, } \\
\text { multiply by }\end{array}$ & U.S. unit & SI unit & $\begin{array}{l}\text { To convert SI to U.S., } \\
\text { multiply by }\end{array}$ \\
\hline 102.7902 & acre-inch(es) & $\mathrm{m}^{3}$ & 0.0097 \\
3.7854 & gal & $\mathrm{L}$ & 0.2642 \\
25.4 & inch(es) & $\mathrm{mm}$ & 0.0394
\end{tabular}


public demand on water supplies and water treatment are factors that are driving the need for efficient management of resources to mitigate production impacts on the environment. As agricultural and urban development intensifies over time, the ability of watersheds to process nutrients will be much more uncertain. Land-use change has been identified as the most significant local, regional, and global human impact on the hydrologic system (Bhaduri et al., 2000).

In general, there is no doubt that we need to take more effective steps to sustainably manage and conserve resources. To do this, we need to effectively coordinate our existing educational resources, to increase the knowledge and capacity of the diverse group of professionals that serve these industries, and to identify the gaps in our knowledge that require further research. Most field (in-soil) producers of ornamental stock use irrigation

\footnotetext{
This project was funded through a section 406 competitive grant from the USDA-CSREES-National Integrated Water Quality Program.

${ }^{1}$ University of Maryland, Department of Plant Science and Landscape Architecture, 2120 Plant Sciences Building, College Park, MD 20742-4452

${ }^{2}$ University of Maryland, Department of Environmental Science and Technology, 1431 AgEngineering Building, College Park, MD 20742-4452
}

${ }^{3}$ North Carolina State University, Department of Horticultural Science, JC Raulston Arboretum, McSwain Education Center, Raleigh, NC 27695

${ }^{4}$ Virginia Tech and State Polytechnic University, Department of Horticulture, 401C Saunders Hall, Blacksburg, VA 24061

${ }^{5}$ Virginia Tech and State Polytechnic University, Department of Forest Resources and Environmental Conservation, 228 Cheatham Hall, Blacksburg, VA 24061

${ }^{6}$ Virginia Tech and State Polytechnic University, Department of Plant Pathology, Physiology and Weed Science, 1444 Diamond Springs Road, Virginia Beach, VA 23455

${ }^{7}$ University of Florida, IFAS, Department of Environmental Horticulture, 2541 Fifield Hall, Gainesville, FL 32611

${ }^{8}$ University of Florida, IFAS, Mid-Florida Research and Education Center, 2725 Binion Road, Apopka, FL 32703

${ }^{9}$ Colorado State University, Department of Horticulture and Landscape Architecture, 213, Shepardson Building, Fort Collins, CO 80523-1173

${ }^{10}$ University of Maryland, Wye Research and Education Center, 124 Wye Narrows Drive, Queenstown, MD 21658

${ }^{11}$ North Carolina State University, Department of Horticultural Science, 64 Kilgore Hall, Raleigh, NC 27695

${ }^{12}$ University of Georgia, Coastal Plain Experiment Station, 0224 Horticulture Building, Tifton, GA 31793

${ }^{13}$ Corresponding author. E-mail: jlc@umd.edu. water during production because of the cost-benefit ratio of maximizing plant growth. While supplemental irrigation is oftentimes necessary for field production, it is essential for container production of ornamental plants. Plants are grown in containers primarily for production efficiency and for ease of shipping to retailers. Container substrates need to be well drained for good root growth and disease management, but in comparison with soil, the lower water-holding capacity of soilless substrates limits the amount of water that can be stored to sustain plant growth. This results in frequent irrigation applications and the use of large daily amounts of water. In a recent survey, over $75 \%$ of nursery crops in 17 states were grown in containers and required daily irrigation (USDA, 2007). In Florida, container nurseries apply 56 to 120 acre-inches of irrigation water per year, in addition to the 40 to 60 inches of average annual rainfall (Fernandez et al., 2009). Container nurseries in Alabama were estimated to have used 9.8 to 13 billion gallons of water in 1985 (Fare et al., 1992), and container nursery production in Alabama has almost tripled since 1987 (USDA, 2004).

Frequent irrigation in combination with high fertilizer and pesticide use can lead to significant losses of agricultural chemicals in runoff water that transports agricultural chemicals to containment structures and/or off-site into groundwater or surface water (Briggs et al., 1998, 2002; Cabrera, 2005; Camper et al., 1994). Irrigation water management is the key to nutrient management in ornamental crop production and to reducing the impact of runoff water on local water resources (Lea-Cox and Ross, 2001; Ross et al., 2001; Tyler et al., 1996; Ullah and Zinati, 2006). However, there are numerous best management practices (BMP's; Yeager et al., 2007) that can be implemented by growers to greatly increase the efficiency of irrigation water applications, decrease leaching fraction, and reduce nutrient (Beeson and Knox, 1991) and pesticide runoff (Mangiafico et al., 2008). For example, increasing the anion and cation exchange capacity of substrates through the use of aluminum or various clay materials can help to reduce leaching of nutrients from soilless substrates (Owen et al., 2008; Williams and Nelson, 1996).
The capture and recycling of water (Yeager et al., 1991) has been shown to dramatically increase the efficiency of nursery production systems, but recycling of runoff water necessitates that growers know and understand pathogen management issues (Hong and Moorman, 2005). The management of residual salts and herbicides is also a concern for the design and sizing of runoff collection structures (Ross, 2008). Thus, the emerging constraints on water use and quality means that the ornamental industry needs research-based information to devise integrated sustainable methods to manage water resources without reducing plant quality and profitability.

Given this situation, we have to ensure that producers are familiar with the most current BMP's, but more importantly, to demonstrate how many of these practices can be implemented at relatively low cost, with careful planning. To achieve this goal, we first need to effectively coordinate our existing educational resources to increase the knowledge and capacity within our research and education community, as well as the industry. The impetus to develop this knowledge center is to integrate our knowledge base of water and nutrient management together with information about substrate, surface water, and pathogen-related issues. All of these interrelated knowledge areas directly or indirectly impact better water and nutrient management decisions by ornamental plant producers. The primary goal of this knowledge center is to educate and increase the knowledge base of individuals to improve production efficiency and the conservation of water and nutrients. The intent is to change practice at the farm level, where necessary. In time, this could also involve the development of multistate BMP's criteria, so that training and certification programs can become less time consuming, more effective, and achieve broader-based accreditation for trainees. We also need to educate other groups as to the breadth of BMP's that have been implemented by the nursery and greenhouse industries and showcase the considerable benefits that many growers are achieving with implementation of these more sustainable practices on their farms. 


\section{Development team and project objectives}

As extension and research faculty from land-grant universities in the mid-Atlantic and southern regions of the United States, the team that developed this knowledge center represents an interdisciplinary group of research and extension professionals who can provide up-to-date, unbiased information on these issues. The genesis of this project was the recognition that we faced similar challenges at the regional and national level in terms of increasing resource use efficiency and the implementation of BMP's. Thus, our primary development objective was to increase the quality of professional knowledge on these issues.

Although each learning module has specific learner objectives, other global objectives are to help people stay informed about the latest BMP's, to improve production practices, to protect the environment, and to increase profitability. Because nurseries are intensive plant production facilities that share essentially the same production characteristics throughout the United States, it is likely that these learning resources will also serve professionals in the central and western United States, and internationally.

\section{Target audiences}

The learning modules were designed with two primary target audiences in mind. First, we wanted to provide information to individual growers, consultants, and other professionals in the nursery and greenhouse industry who wish to fulfill personal, business development, and/or state certification requirements (e.g., Maryland Department of Agriculture, 2009). The modules were designed to be "self-supporting" in that learners can work through the resources (module content, assignments, self-assessment quizzes, etc.) at a time and place convenient to the individual. This approach was taken because none of the faculty involved had the time to devote to the active daily support of these resources, except through formalized course offerings.

We, however, also designed the learning modules to offer a more rigorous course offering for undergraduate students at community colleges and 4-year institutions. We recognized in doing this that we could also serve distributed partner networks of educators at community colleges and other universities to provide them with the resources for inclusion in other course offerings. Another important target audience was countyand regional-based extension faculty, who could use the knowledge not only for their own use, but for use in outreach presentations to growers and other professionals in their local communities. We have found that this assisted learning mode is important for many students because they are more comfortable in a more structured (guided) learning environment.

\section{The Knowledge Center}

The Knowledge Center comprises two areas: a standard website and a more in-depth active learning area, developed with Moodle software (version 1.9; Moodle Trust, Perth, Australia).

The website (Zhao and LeaCox, 2007). The website is the public gateway (Fig. 1) and provides general informational resources on the project, the industry, regulations specific to each state, our partners, and direct links to the knowledge center learning modules. The information on this website is targeted at people who may not be familiar with the nursery and greenhouse industry or our specific water and nutrient management goals. We provide general information about the nursery and greenhouse industry in the southeastern United States, with statistics from the six states who are primary partners in this endeavor. General regulatory information is also given on the website, as this is often a primary reason that people initially search for information. The concept of BMP's also is introduced because the general public is unlikely to be familiar with this concept as an integrated production approach by commercial operations. We also briefly explain on the website how these modules are currently used for accreditation and certification, with links to the various state and industry organizations who are our partners in this process. Last, we provide biographies of the faculty at the six landgrant institutions who developed the learning modules.
The Learning Modules (Green Industry Knowledge Center, 2008). The learning modules provide access to more than 25 in-depth modules (Fig. 2) with specific information on substrates, irrigation, and nutrient and crop health management. Additionally, surface water management modules provide detailed information on engineering aspects of containment pond design, BMP's recommendations for recycling and water treatment, and audit tools to assess and improve the efficiency of existing systems. Additional modules cover advanced irrigation scheduling tools and water-saving technology, together with three modules on water-borne pathogen management. The learning modules were designed to engage learners in these diverse topics, as they are all integral to formulating farm-specific strategies for effective water and nutrient management. The learning module homepage (Fig. 2) was specifically designed to show the macro-level organization of all 25 modules, ranging from introductory to more advanced modules. Over 50 regulatory agency, industry, and education professionals were active in the developmental review of these resources, through face-to-face workshops and online content reviews.

\section{Development approach}

The Learning environment: Moodle. To provide a framework for the learning modules, we chose a web-based format for delivery, as professionals are routinely busy and widely dispersed throughout the region. We specifically chose to develop the modules within Moodle because it is an extremely cost-effective, opensource software package for developing and hosting web-based courses and advanced websites. Moodle is a learning management system and is available as a free download; however, hosting the Moodle software requires a server with various supporting software. This usually requires the support of an information technology professional in the organization to ensure the installation, optimization, and security of the various program features. However, once installation is complete, the design and maintenance of course modules can easily be undertaken by faculty and/or staff. Moodle is a very easy-to-use learning 


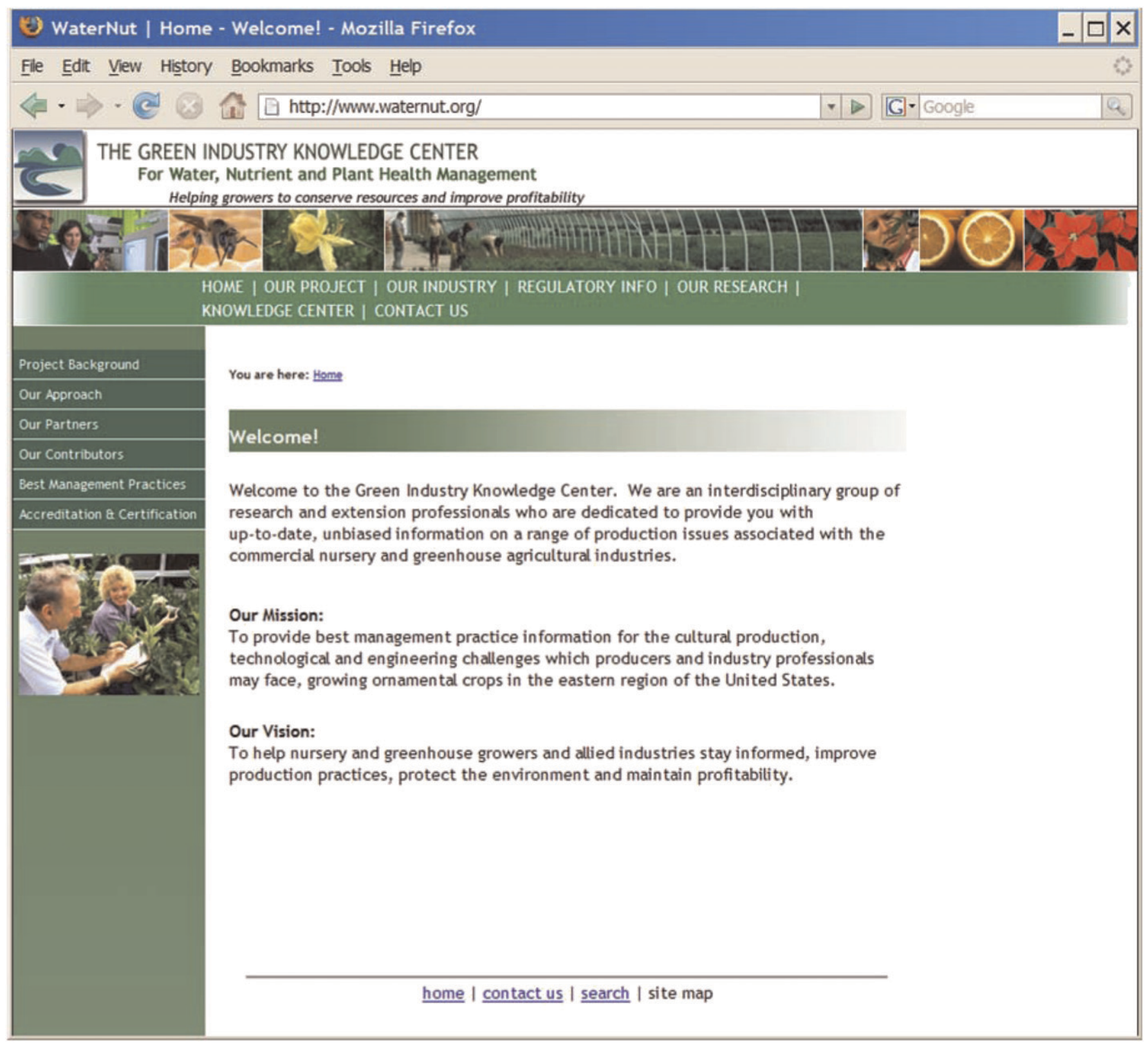

Fig. 1. The green industry knowledge center website provides general information about the background, approach, partners, and contributors to the knowledge center project.

management system that is primarily designed to support a social, constructionist framework of education. It is these benefits that have made Moodle the choice for teachers and organizations all over the world. Moodle currently has 56,264 registered sites in 210 countries, providing nearly 3 million courses, with more than 32 million registered users (Moodle, 2009).

The chief limitation for many online course developers is working within an environment that is userfriendly not only for the learner, but also the developer, and balancing the development issues with programmatic and long-term support issues for the site. It was one of the most important decisions that we made as the development team because the appearance and readability of the modules, together with ease of access and the functionality (e.g., navigation) of the final education experience, is extremely important to the learner (Lea-Cox et al., 2002). Of course, the integration of other functions within the software environment, such as the "My course" functions, discussion areas, blogs, and the other tools that make the user feel part of the course are also extremely important, to ensure that the technology does not inhibit the learning experience (Pallof and Pratt, 1999).

LEARNING MODULE DEVELOPMENT. The distance-learning environment allows us to combine the rich text and graphic environment with the immediacy of delivery in a continuously available setting. Within a password-protected courseware environment, the information "content" can be systematically designed such that learning materials are presented in a coherent and logical format. Learning management systems provide the 


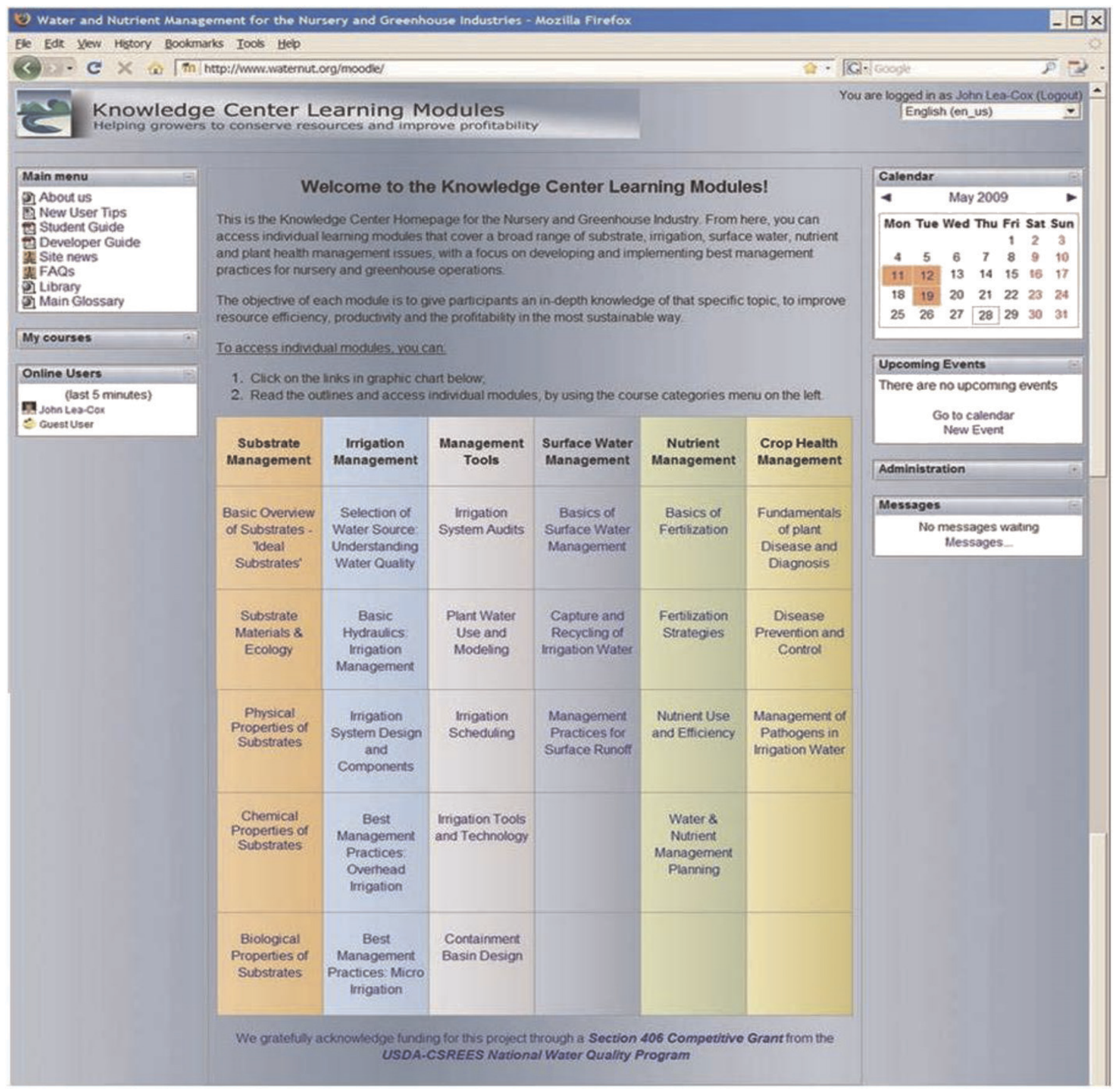

Fig. 2. The knowledge center modules, using Moodle (Moodle Trust, Perth, Australia) as the learning management system. The site provides access to 25 discrete learning modules on substrate, irrigation, surface water, nutrient, and crop health management.

educational designer with a large degree of design control and tool capabilities, together with user-tracking capabilities. It is for these reasons that learning management systems have become the de facto standard for distance learning in the web-based environment, rather than html web pages.

That being said, faculty should recognize that learning modules require a great deal of planning and good instructional design (Lea-Cox et al., 2002) because often the learner does not have the benefit of understanding the context of information that can be more easily communicated in a face-to-face environment. For this reason, each module has stated learner objectives, so the person reviewing the information provided can understand what the teachers are trying to convey. Some developers also choose to write content and assignments in the first person, to provide a more communicative approach. Each learning module covers the science or subject matter necessary to understand the concept or process (Figs. 3 and 4). As stated previously, this subject matter includes the discussion of substrate, irrigation, surface water, and nutrient and pathogen management from a number of different approaches. Each module is designed to provide the user with a range of activities and 


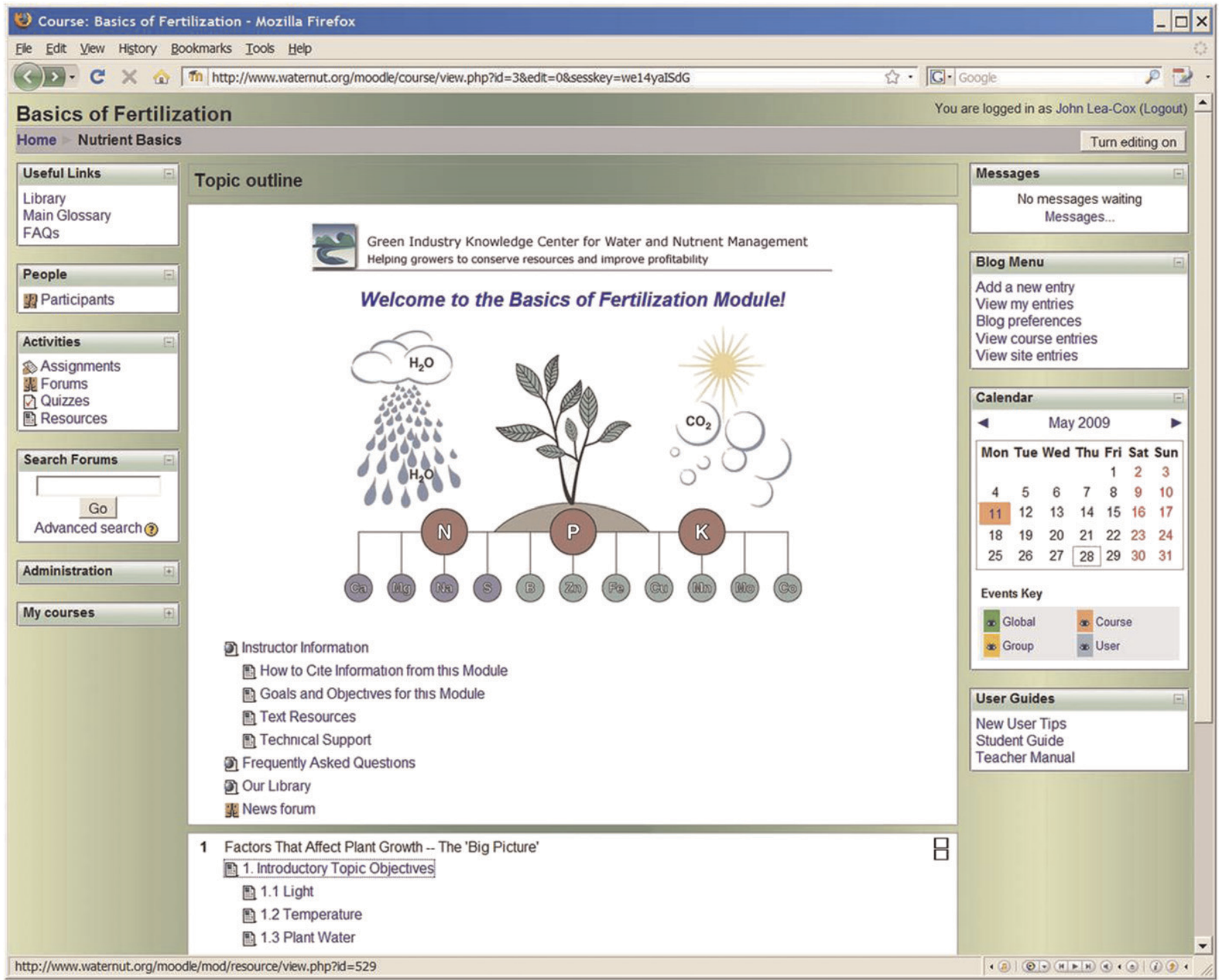

Fig. 3. A example of learning module homepage: "Basics of Fertilization." Each module is constructed to provide learners with an interactive learning experience on a specific topic, with the focus on sustainable best management practices.

assignments to demonstrate key concepts and/or reinforce material through realistic scenarios such as case studies. The student is actively engaged by accessing multiple types of media such as text resources, hypertext links to external websites and PDF resources, photographs, graphic illustrations, and PowerPoint (Microsoft, Redmond, WA) slides and video clips, where appropriate. Each learning module also contains evaluation methods (self-assessment quizzes, games, and assignments) that are designed to synthesize knowledge and comprehension.

Problem based as Well as KNOWLEDGE BASED. We have a number of modules that are entirely practical -two specific examples being an irrigation audit module (Fig. 4), where the grower is guided through a specific protocol to optimize the performance of the irrigation system, and another being a water and nutrient management planning module, which guides the grower through a process to write a site-specific best management plan for their operation. By using a problem-based learning approach and with guidance from information contained in the module, learners are challenged to analyze, synthesize, and evaluate information to enable them to design and implement a customized plan for their operation. We combine realistic case studies with practical assignments to demonstrate key points so that people can think critically about issues and formulate a suite of economic best management strategies that make sense for their specific operation.

\section{User statistics}

During the first year since officially being released, the knowledge center has experienced a steady increase in monthly visits (Fig. 5) from less than 100 visits during June 2008 to over 3000 visits in Apr. 2009. The majority of those visits were from new visitors, but there were an increasing proportion of return visitors during this time. Registered users increased steadily from fewer than 100 in July 2008 to more than 450 in June 2009. Over $45 \%$ of the registered users accessed the site repeatedly. There were 195 active users from 28 countries during the first 


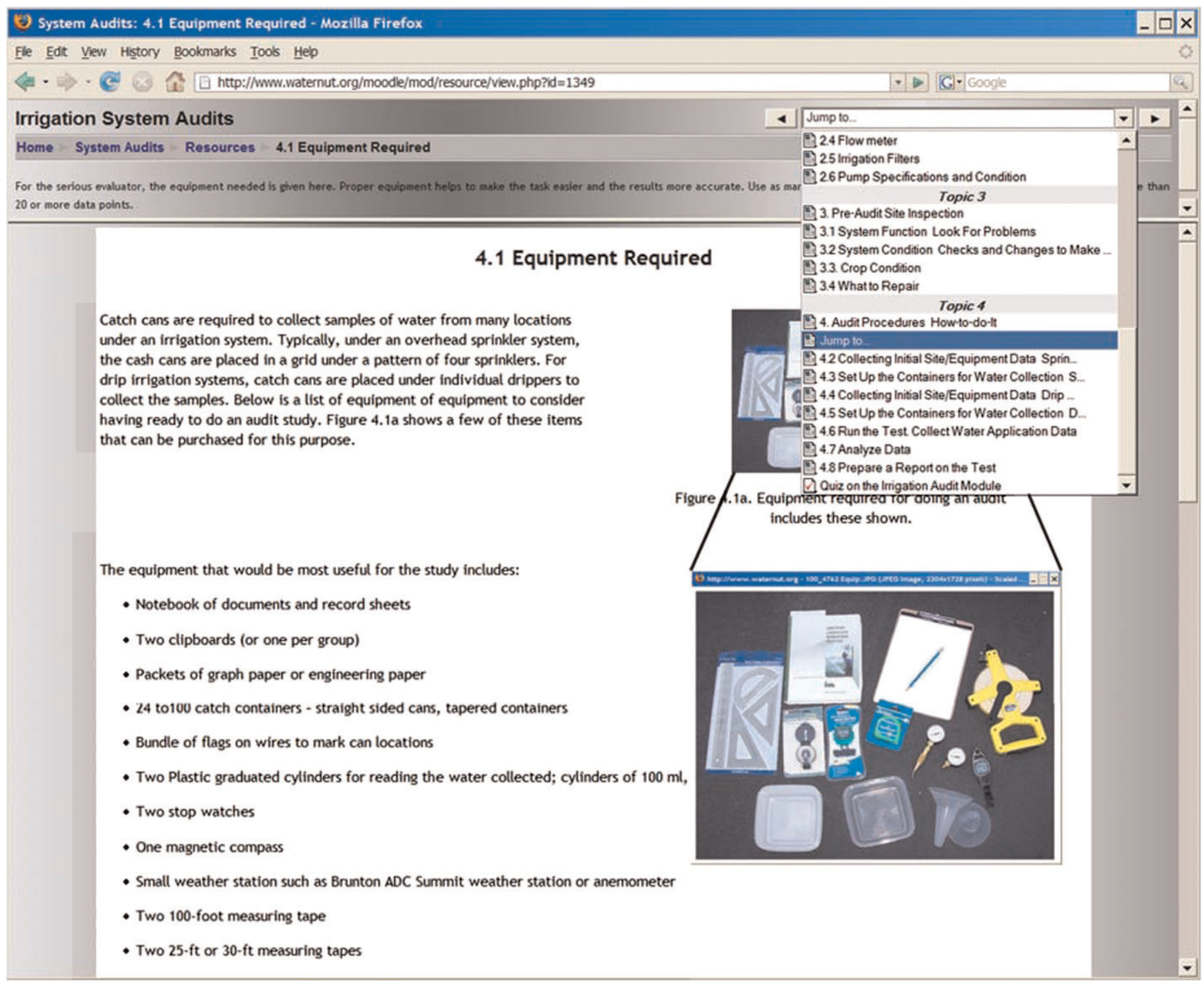

Fig. 4. An example of a content page, showing various navigation methods. The Moodle (Moodle Trust, Perth, Australia) learning environment is quite intuitive and allows the learner to easily access information and communicate with course instructors and participants, using various tools such as discussion forums and chat.

6 months of 2009, who accessed an average of eight pages per visit.

During Spring 2008, a new 400level course entitled "Principles of Substrate, Water and Nutrient Management" was taught at the University of Maryland, using 15 of the 25 learning modules in the knowledge center. A total of 11 undergraduate and three graduate students from the plant sciences, engineering, and business management disciplines registered for the course. This course is offered as four 1 -credit courses that run sequentially through the Spring semester. Each course (substrate, irrigation, and surface water and nutrient management) can be taken as a separate unit or can be combined into a complete four-credit course. Each course uses at least three learning modules from the knowledge center, and is supported by an instructor who conducts a 3-h face-toface laboratory or summary session at the end of each course so that the students have an opportunity to ask questions or conduct hands-on assignments. Syllabi for each of these courses can be found on the University of Maryland, Department of Plant Science and Landscape Architecture (2009) website. During Spring 2009 , we had a total of 16 undergraduate and two graduate students register for one or more of these courses; eight students registered for all four credits. These courses can also be taken for professional certification. Nine students were nonplant science majors (economics, business, and environmental science and policy majors). During 2009, we also had four industry professionals and one county extension educator register for all four credits. We currently have an agreement with the Maryland Department of Agriculture, who certifies continuing nutrient management education units (CEU) for nursery and greenhouse professionals in the state. Each completed online module is awarded three CEU upon verification.

We are currently in discussion with some grower organizations to develop a BMP's certification process for growers through the offering of 


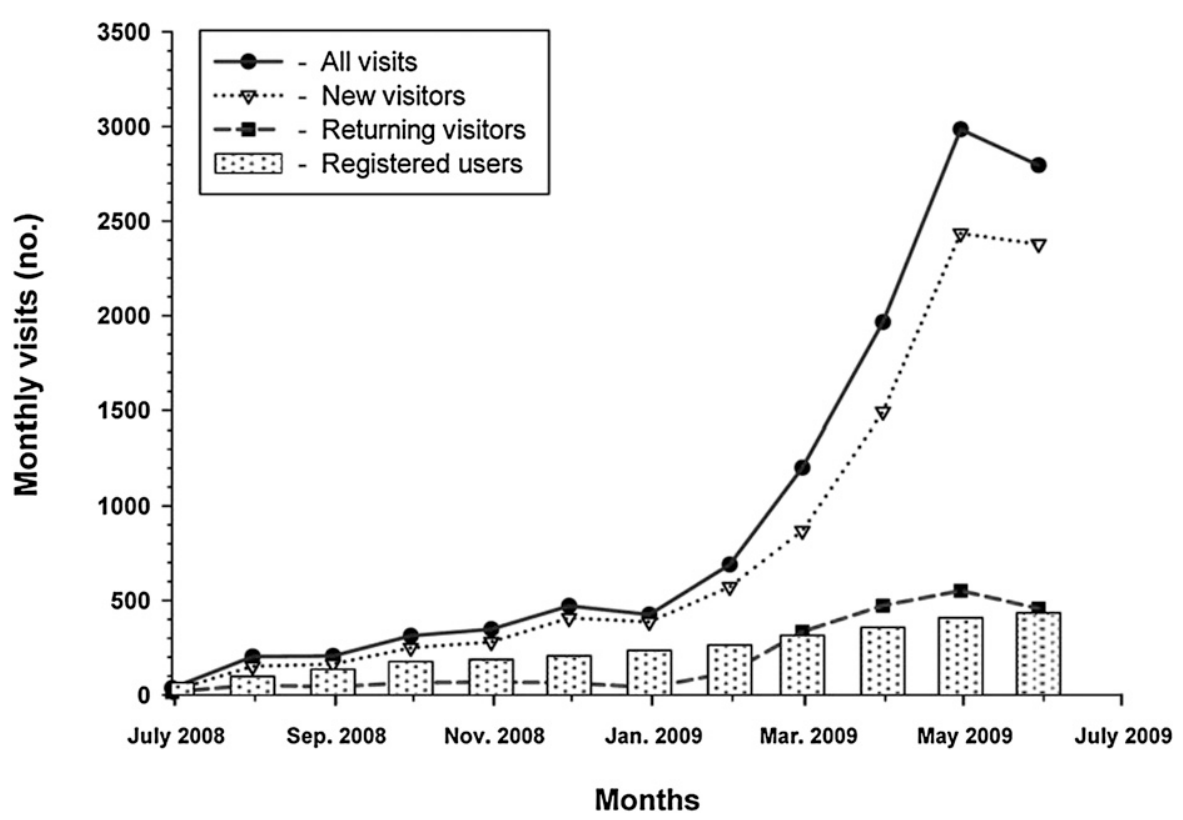

Fig. 5. Summary knowledge center user statistics from public release in July 2008 to the present, illustrating all new, returning, and registered visitors. The site does allow guest access to certain modules, which contributes to about half of the normal daily traffic on the site.

these online modules. We have concentrated on building a community of practice during the development years of this project and we anticipate a continuing increase in users in future years.

\section{Evaluation and impacts}

We need to continuously evaluate our impact by asking the question "How do these extension education activities affect decision-making, management practices, and behavior changes among our students, growers, and professionals?" Currently, many stakeholders in this industry do not have the resources available to make actively engaged BMP's decisions because these production systems differ so radically from traditional agronomic-type operations in terms of water and nutrient use. As a part of implementation of nutrient management plans in Maryland, we are currently conducting a study to measure the impact of our nutrient management planning efforts (Majsztrik et al., 2009). The continued use and access of online resources are an important part of this strategy, as well as the development of additional modules and tools. Our wish is to facilitate the active learning process so that the enduser can come to a rational decision on how to change practice for economic, environmental, or personal reasons. We actively assess how this knowledge affects individual actions by providing anonymous online surveys at the end of every module, which we use to renew and refine our content on a continuous basis. Ultimately, we hope that the continued use and development of this knowledge center will facilitate public policy education, individual action to improve water conservation and reduce runoff, thereby increasing the water quality of operations within the regions' watersheds, and improve our ability to form partnerships between cooperative extension and state and federal agencies.

\section{Literature cited}

Beeson, R.C., Jr., and G.W. Knox. 1991. Analysis of efficiency of overhead irrigation in container production. HortScience 26:848-850.

Beeson, R.C., Jr., M.A. Arnold, T.E. Bilderback, B. Bolusky, S. Chandler, H.M. Gramling, J.D. Lea-Cox, J.R. Harris, P.J. Klinger, H.M. Mathers, J.M. Ruter, and T.H. Yeager. 2004. Strategic vision of container nursery irrigation in the next ten years. J. Environ. Hort. 22: $113-115$.

Bhaduri, B., J. Harbor, B. Engel, and M. Grove. 2000. Assessing watershed-scale, long-term hydrologic impacts of land-use change using a gis-nps model. Environ. Manage. 26:643-658.

Briggs, J.A., M.B. Riley, and T. Whitwell. 1998. Quantification and remediation of pesticides in runoff water from containerized plant production. J. Environ. Qual. $27: 814-820$.

Briggs, J.A., T. Whitwell, R.T. Fernandez, and M.B. Riley. 2002. Effect of integrated pest management strategies on chlorothalonil, metalaxyl and thiophanate-methyl runoff at a container nursery. J. Amer. Soc. Hort. Sci. 127:1018-1024.

Cabrera, R.I. 2005. Challenges and advances in water and nutrient management in nursery and greenhouse crops. Agr. Mediterranean 135:147-160.

Camper, N.D., T. Whitwell, R.J. Keese, and M.B. Riley. 1994. Herbicide levels in nursery containment pond water and sediments. J. Environ. Hort. 12:8-12.

Fare, D.C., C.H. Gilliam, and G.J. Keever. 1992. Monitoring irrigation at container nurseries. HortTechnology 2: 75-78.

Fernandez, R.T., J.D. Lea-Cox, G. Zinati, C. Hong, R. Cabrera, D. Merhaut, J. Albano, M. van Iersel, T.H. Yeager, and D. Buhler. 2009. NCDC216: A new multistate group for water management and quality for ornamental crop production and health. Proc. Southern Nursery Assn. Res. Conf. 54:35-38.

Green Industry Knowledge Center. 2008. Green industry knowledge center for water, nutrient and crop health management learning modules. 5 Aug. 2009. <http:// www.waternut.org/moodle>.

Hong, C.X. and G.W. Moorman. 2005. Plant pathogens in irrigation water: Challenges and opportunities. Crit. Rev. Plant Sci. 24:189-208.

Lea-Cox, J.D. and D.S. Ross. 2001. Clean water policy and the rationale for developing a water and nutrient management process for container nursery and greenhouse operations. J. Environ. Hort. 19: 226-229.

Lea-Cox, J.D., E.N. Varley, D.S. Ross, and K.M. Teffeau. 2002. Using webbased distance learning methods to teach nutrient management planners. HortTechnology 12:736-740.

Majsztrik, J., J.D. Lea-Cox, A.G. Ristvey, and D.S. Ross. 2009. Modeling water and nutrient runoff from nursery and greenhouse operations in Maryland. Proc. Southern Nursery Assn. Res. Conf. 54: 201-207.

Mangiafico, S.S., J. Gan, L. Wu, J. Lu, J.P. Newman, B. Faber, D.J. Merhaut, and R. Evans. 2008. Detention and recycling 
basins for managing nutrient and pesticide runoff from nurseries. HortScience 43:393-398.

Maryland Department of Agriculture. 2009. Office of resource conservation: Nutrient management. 5 Aug. 2009. <http://www.mda.state.md.us/resource conservation/nutrient_management/ index.php $>$.

Moodle. 2009. Open-source course management system. 5 Aug. 2009. <http:// moodle.org/about $>$.

Owen, J.R., S. Warren, T. Bilderback, and J. Albano. 2008. Phosphorus rate, leaching fraction, and substrate influence on influent quantity, effluent nutrient content, and response of a containerized woody ornamental crop. HortScience 43:906-912.

Pallof, R.M. and K. Pratt. 1999. Building learning communities in cyberspace: Effective strategies for the online classroom. Jossey-Bass, San Francisco, CA.

Ross, D.S. 2008. Containment basin design. In: J.D. Lea-Cox, D.S. Ross, and C. Zhao (eds.). Green industry knowledge center for water, nutrient and crop health management5 Aug. 2009. <http://www. waternut.org/moodle/course/view. php?id=29>.

Ross, D.S., J.D. Lea-Cox, and K.M. Teffeau. 2001. The importance of water in the nutrient management process. Proc. Southern Nursery Assn. Res. Conf. 46: 588-591.

Tyler, H.H., S.L. Warren, and T.E. Bilderback. 1996. Reduced leaching fractions improve irrigation use efficiency and nutrient efficacy. J. Environ. Hort. 14: 199-204.

Ullah, S. and G.M. Zinati. 2006. Denitrification and nitrous oxide emissions from riparian forests exposed to prolonged nitrogen runoff. Biogeochemistry 81:253-267.

U.S. Department of Agriculture. 2004. 2002 census of agriculture. 5 Aug. 2009. <http:// www.agcensus.usda.gov/Publications/ 2002/index.asp>.

U.S. Department of Agriculture. 2007. Nursery crops 2006 summary. 5 Aug. 2009. <http://www.nass.usda.gov/Statistics by_State/Washington/Publications/ Annual_Statistical_Bulletin/2008/ ab129-154.pdf>.
University of Maryland, Department of Plant Science and Landscape Architecture. 2009. PLSC 461-4: Cultural management for nursery and greenhouse operations. 5 Aug. 2009. <http://www.psla.umd.edu/ faculty/lea-cox/index.cfm $>$.

Williams, K.A. and P.V. Nelson. 1996. Modifying a soilless root medium with aluminum influences phosphorus retention and chrysanthemum growth. HortScience 31:381-384.

Yeager, T.H., R.H. Harrison, and D.L. Ingram. 1991. 'Rotundifolia' holly growth and nitrogen accumulation influenced by supraoptimal root-zone temperatures. HortScience 26:1387-1388.

Yeager, T.H., T.E. Bilderback, D. Fare, C. Gilliam, J.D. Lea-Cox, A.X. Niemiera, J.M. Ruter, K. Tilt, S. Warren, T. Whitwell, and R.D. Wright. 2007. Best management practices: Guide for producing nursery crops, 2nd ed. Southern Nursery Assn, Atlanta, GA.

Zhao, C. and J.D. Lea-Cox. 2007. The green industry knowledge center website for water, nutrient and crop health management. 5 Aug. 2009. <http://www. waternut.org $>$. 